\title{
Genetic mapping of leaf-related traits in autotetraploid alfalfa (Medicago sativa $\mathrm{L}$.)
}

\author{
Fei He • Junmei Kang • Fan Zhang • Ruicai Long • \\ Long-Xi Yu • Zhen Wang • Zhongxiang Zhao • \\ Tiejun Zhang • Qingchuan Yang
}

Received: 28 November 2018 / Accepted: 8 September 2019/Published online: 9 November 2019

(C) The Author(s) 2019

\begin{abstract}
Understanding the genetic architecture of leaf-related traits is important for improving alfalfa yield. Leaf size has a great influence on the protein content and yield for alfalfa. In this study, a low-
\end{abstract}

Fei He and Junmei Kang contributed equally to this work.

F. He · J. Kang $\cdot$ F. Zhang $\cdot$ R. Long $\cdot$ Z. Wang $\cdot$

T. Zhang $(\bowtie) \cdot$ Q. Yang $(\triangle)$

Institute of Animal Sciences, Chinese Academy of Agricultural

Sciences, Beijing, China

e-mail: tiejunzhang@126.com

e-mail: qchyang66@163.com

\section{F. He}

e-mail: hefei0609@126.com

J. Kang

e-mail: kangjmei@126.com

F. Zhang

e-mail: 15600085453@163.com

R. Long

e-mail: dragongodsgod@163.com

\section{Z. Wang}

e-mail: wangzhen@caas.cn

L.-X. Yu

Plant Germplasm Introduction and Testing Research, United States Department of Agriculture-Agricultural Research Service, Prosser, WA, USA

e-mail: longxi.yu@ars.usda.gov

Z. Zhao

Vocational College of Technology, Cangzhou, China e-mail: zzx-0614@163.com yielding precocious alfalfa individual (paternal parent) and a high-yielding late-maturing alfalfa individual (maternal parent) were used to build a hybrid $\mathrm{F}_{1}$ population of 149 individuals. The linkage map was constructed using simple sequence repeat and single nucleotide polymorphism markers, and quantitative trait loci (QTL) for leaf length, leaf width, and leaf area were mapped using 3 years phenotypic data. We identified a total of 60 QTLs associated with leaf size. These QTLs were located on chromosomes 1 to 8 , and the percent of phenotypic variation explained by QTL ranged from $2.97 \%$ to $18.78 \%$. There were 13 QTLs explain more than $10 \%$ of phenotypic variation, most of which represent novel loci controlling leaf traits that have not been found in previous studies. The nearest markers of QTL may be used in marker-assisted selection and breeding alfalfa new varieties with high yield.

Keywords Alfalfa · Leaflength · Leaf width · Leaf area • Quantitative trait loci

\section{Introduction}

Alfalfa (Medicago sativa L.) is one of the most important legumes used for forage worldwide because of its high yield and good nutritional value (Adhikari et al. 2018). Leaves are one of the most important targets for improvement by breeders because they are essential organs with high protein content and good palatability, providing the plant with a large amount of organic matter and energy (Zhang et al. 2016), and thus playing 
a vital role in increasing yield. Leaves are the primary sites of photosynthesis in plants, and leaf size is related to photosynthetic capacity (Bhagsari 1990). For example, photosynthetically active radiation use efficiency is reduced in smaller leaves. Because leaf area (LA) and leaf distribution affect the amount of solar radiation captured, these traits affect crop photosynthesis (Stewart et al. 2003) and growth rate and transpiration (Lieth et al. 1986). Thus, to improve the yield and quality of alfalfa, it is necessary to increase photosynthetic efficiency by enhancing leaf-related traits, such as leaf length (LL), leaf width (LW), and leaf area (LA).

The genetic control of leaf traits in alfalfa is not well known, and investigation into the endogenous factors influencing leaf traits will be valuable for developing cultivars with high yield. In QTL mapping, phenotypic information and genotype information are combined to determine the chromosomal locations of genetic variants that are associated with a trait (Tanksley 1993). It is a powerful tool for analyzing the genetic basis of complex agronomic traits, and it is also a useful method for elucidating the genetic architecture of agronomic traits such as leaf size. Therefore, identifying QTLs underlying phenotypic variation in alfalfa leaf size will facilitate the breeding of alfalfa cultivars with high protein content and high yield.

There has been extensive QTL mapping of leafrelated traits in many crops such as rice, wheat, and maize. In maize, different QTLs for leaf morphology, which is usually only studied in terms of size, length, and width, have been mapped in different chromosomes and locations. In addition, genetic regions associated with leaf-related traits under different environmental conditions have also been identified by performing genome-wide association analysis of maize nested association mapping populations (Feng et al. 2015) and QTL mapping in $\mathrm{F}_{2}$ and recombinant inbred line (RIL) populations ( $\mathrm{Li}$ et al. 2015a). Indicating that the genetic control of leaf morphology is complex (Cai et al. 2012; Ku et al. 2012; Wassom 2013) and QTL mapping results differ between environments (Hou et al. 2015). QTLs for leaf size-related traits have also been mapped in other crops. For example, QTLs for leaf area (Cui et al. 2003; Ishimaru et al. 2001) and LL and LW have been identified in rice (Kobayashi et al. 2004; Tong et al. 2007) and the QTL loci related to leaf traits were also identified in wheat and white clover (Cogan et al. 2006; Jia et al. 2013; Wu et al. 2015). Relatively few studies of leaf-related traits have been identified in alfalfa, and these QTLs provide a theoretical method for alfalfa localization.

Genetic analysis of leaf-related traits in plants through QTL mapping requires adequate genome coverage with molecular markers. A large number of single nucleotide polymorphisms (SNPs) can be obtained cost effectively through next-generation sequencing methods such as RAD-seq (restriction-site associated DNA), even in species with no prior genome assemblies (Mansur et al. 1993). The extensive natural variation in alfalfa and the availability of a high-density genetic linkage map provide the basis for accurate localization of alfalfa leaf QTLs and the causal genes. The published QTL studies in alfalfa have mainly focused on traits such as flowering time (Pierre et al. 2008), seed mineral concentration and content (Sankaran et al. 2009), seed germination and growth before seedling emergence (Dias et al. 2011), and seed vigor (Vandecasteele et al. 2011). Previous conducted QTL mapping for the fall dormancy and winter hardiness traits of alfalfa, they used the GBS (genotyping-by-sequencing) technique and two varieties as materials, and they mapped 45 QTLs that were significantly associated with fall dormancy and 35 QTLs related to winter hardiness (Adhikari et al. 2018). Previous identified 71 QTLs related to plant height and winter injury in an F1 population of alfalfa (Li et al. 2015b). However, these QTLs were concentrated on sites containing QTLs for yieldrelated alfalfa traits, and there have been few QTL studies on alfalfa leaf traits. Avia (Avia et al. 2013) identified a few QTLs related to LA on 1, 3, and 4 chromosome of Medicago truncatula. Previous studies have also found QTLs associated with LA in M. truncatula (Arraouadi et al. 2011). These studies provide useful information for our current study.

Leaf-related traits are essential and vary widely in nature. Studies to quantify overall leaf shape variation are necessary to identify complete complements of genes that determine differences in leaves between populations (Chitwood et al. 2012a, b, c). Considering the difference in gene composition, we can analyze the genetic traits of specific in a species by comparing the similar traits in different populations. Identifying QTLs underlying leaf traits in alfalfa will enable the identification of the genetic factors controlling these traits and aid the discovery of markers associated with yieldrelated trait. Nearest markers of these QTL can be used for marker-assisted selection and breeding alfalfa cultivars with high yield after validation. 
Table 1 Traits associated with leaf size in the F1 population and parental lines in 2016, 2017 and 2018

\begin{tabular}{|c|c|c|c|c|c|c|c|c|c|c|}
\hline Year & Trait & $\begin{array}{l}\text { Number of } \\
\text { plants }\end{array}$ & $\begin{array}{l}\text { Female parent } \\
\text { mean }\end{array}$ & $\begin{array}{l}\text { Maternal parent } \\
\text { mean }\end{array}$ & $\begin{array}{l}\text { Population } \\
\text { mean }\end{array}$ & $\mathrm{CV}$ & $\mathrm{Z}$ test & Skewness & Kurtosis & $H^{2}$ \\
\hline \multirow[t]{3}{*}{2016} & LL & 149 & 2.6 & 5.4 & $2.69 \pm 0.32$ & 0.14 & $P<0.01$ & -0.38 & 0.06 & 0.45 \\
\hline & LW & 149 & 1.2 & 2.4 & $1.67 \pm 0.18$ & 0.17 & $P<0.01$ & -0.4 & 0.23 & 0.51 \\
\hline & LA & 149 & 2.33 & 6.52 & $2.93 \pm 0.26$ & 0.32 & $P<0.01$ & 0.55 & -0.27 & 0.63 \\
\hline \multirow[t]{3}{*}{2017} & LL & 149 & 2.1 & 4.9 & $1.77 \pm 0.27$ & 0.26 & $P<0.01$ & 1.13 & 0.66 & 0.41 \\
\hline & LW & 149 & 0.9 & 2 & $1.89 \pm 0.15$ & 0.23 & $P<0.01$ & 0.65 & -1.21 & 0.49 \\
\hline & LA & 149 & 2.14 & 4.64 & $1.30 \pm 0.23$ & 0.36 & $P<0.01$ & 0.84 & 0.5 & 0.62 \\
\hline \multirow[t]{3}{*}{2018} & LL & 149 & 2.8 & 5.5 & $3.55 \pm 0.26$ & 0.31 & $P<0.01$ & 0.71 & 1.12 & 0.41 \\
\hline & LW & 149 & 1.2 & 1.8 & $1.81 \pm 0.14$ & 0.19 & $P<0.01$ & 0.68 & 0.48 & 0.52 \\
\hline & LA & 149 & 2.8 & 5.73 & $4.4 \pm 0.28$ & 0.31 & $P<0.01$ & 0.95 & 0.57 & 0.66 \\
\hline
\end{tabular}

$L L$ leaf length, $L W$ leaf width, $L A$ average leaf area, $C V$ coefficient of variation, $H^{2}$ broad-sense heritability

\section{Materials and methods}

Plant material and growth conditions

Two parental genotypes, separated from local variety "Cangzhou" (CF000735) (maternal parent) and variety Zhongmu NO.1 (CF032020) (paternal parent), the two individuals were crossed to generate an $\mathrm{F}_{1}$ population consisting of 149 progeny lines. The phenotypic data of LL, LW, and LA were collected in 2016, 2017, and 2018 at the field of Chinese Academy of Agricultural Sciences in Langfang, Hebei province, China. The annual average temperature is $11.9^{\circ} \mathrm{C}$, the average temperature in the coldest month (January) is minus $4.7^{\circ} \mathrm{C}$, and the average temperature in the hottest month (July) is $26.2{ }^{\circ} \mathrm{C}$. The annual precipitation is $554.9 \mathrm{~mm}$, and

Table 2 Correlation coefficients for leaf size-related traits in 2016, 2017 and 2018

\begin{tabular}{lllll}
\hline Year & Trait & LA & LL & LW \\
\hline 2016 & LA & 1.00 & $0.818^{* * *}$ & $0.866^{*}$ \\
& LL & & 1.00 & $0.434^{* *}$ \\
& LW & & & 1.00 \\
2017 & LA & 1.00 & $0.506^{* *}$ & $0.609^{* *}$ \\
& LL & & 1.00 & $0.307^{* *}$ \\
& LW & & & 1.00 \\
2018 & LA & 1.00 & $0.617^{* *}$ & $0.789^{* *}$ \\
& LL & & 1.00 & $0.370^{* *}$ \\
& LW & & & 1.00 \\
\hline
\end{tabular}

$L A$ leaf area, $L L$ leaf length, $L W$ leaf width

**A significant correlation at the 0.01 level (two-sided) precipitation is unevenly distributed throughout the year and is mostly concentrated in summer. The soil is medium loam soil, containing $1.69 \%$ organic matter, with a $\mathrm{pH}$ value of 7.37. The detail of field experiment design was described in our previous study (Zhang et al. 2019). No fertilizer or irrigation was applied, and weeding was done manually. The remaining $5 \mathrm{~cm}$ mowing was performed on each individual plant before winter, thus ensuring consistency between individuals.

Phenotype measurement

LL, LW, and LA were measured using a handheld leaf area meter. The handheld leaf area meter uses the principle of photoelectric induction, and the blade can be measured by simply spreading the blade on the photosensitive plate. Beginning on May 1, each individual plant randomly selected three leaves for measurement. After entering the normal measurement state, the photosensitive plate of the instrument was opened, the petiole was removed, and measurements were made from three blades randomly selected from each individual plant for leaf traits. When the instrument displayed the measurement, the blade was pulled slowly and smoothly, that is, the LL, LW, and LA are completed. Finally, the average result of multiple measurements was obtained by pressing the "Average" key.

\section{Genetic linkage map}

The linkage map information is reported in a separate study (Zhang et al. 2019). In brief, Medicago sativa L. were sequenced using the RAD-seq method. SNP data 
Table 3 Variance components of leaf length, leaf width, and leaf area in an alfalfa population

\begin{tabular}{|c|c|c|c|c|c|c|}
\hline & & $\mathrm{df}$ & Type III SS & Mean square & F-value & Significance \\
\hline \multirow{4}{*}{ Leaf area } & Genotype (G) & 149 & 350.63 & 2.29 & 2.51 & $* * *$ \\
\hline & Year $(Y)$ & 2 & 1747.11 & 873.55 & 957.48 & $* * *$ \\
\hline & $\mathrm{G} \times \mathrm{Y}$ & 301 & 471.68 & 1.57 & 1.72 & $* * *$ \\
\hline & Genotype (G) & 149 & 141.69 & 0.93 & 1.4 & $* * *$ \\
\hline \multirow[t]{3}{*}{ Leaf length } & Year (Y) & 2 & 603.94 & 301.97 & 456.62 & $* * *$ \\
\hline & $\mathrm{G} \times \mathrm{Y}$ & 297 & 256.37 & 0.86 & 1.31 & $* * *$ \\
\hline & Genotype (G) & 149 & 90.09 & 0.59 & 0.72 & $* * *$ \\
\hline \multirow[t]{2}{*}{ Leaf width } & Year (Y) & 2 & 5.61 & 2.81 & 3.42 & $*$ \\
\hline & $\mathrm{G} \times \mathrm{Y}$ & 297 & 197.07 & 0.66 & 0.81 & $* * *$ \\
\hline
\end{tabular}

*Significant at the 0.05 probability level; **significant at the 0.01 probability level; ***significant at the 0.001 probability level

were called using the Universal Network Enable Analysis Kit (UNEAK) pipeline ( $\mathrm{Lu}$ et al. 2013). SNP markers with more than $50 \%$ missing values were removed, and single-dose alleles (SDA, AAAB X AAAA) with a segregation ratio of less than 2:1 among F1 progenies were used to construct a genetic linkage map using Joinmap. SNP (single nucleotide polymorphism) data were added during linkage map construction. There were 2317 SDA SNP markers in P1 (paternal parent) and 4553 SDA SNP markers in P2 (maternal parent). For SNP markers, there were 56 and 84 SDA markers in $\mathrm{P} 1$ and $\mathrm{P} 2$, respectively. The final $\mathrm{P} 1$ linkage map spanned a total of $3455 \mathrm{cM}$ with 1153 mapped markers and an average marker density of $3.00 \mathrm{cM}$. The P2 linkage map spanned a total of $4381 \mathrm{cM}$ with 3312 mapped markers and an average marker density of $1.32 \mathrm{cM}$.

\section{QTL mapping}

QTL analysis was performed to identify QTLs related to leaf traits and to calculate the contribution rate and additive effect of each QTL. QTL mapping was analyzed using the additive composite interval mapping method (ADD-ICIM) of the QTL IciMapping software (Institute of Crop Science, Chinese Academy of Agricultural Sciences CAAS, Beijing, China) (Lei et al. 2015). The phenotype (LL, LW, and LA) and genotype data for each plant in the $\mathrm{F} 1$ population were combined, and QTLs were mapped using the BIP function (Lei et al. 2015) in QTL IciMapping with a LOD threshold of 3. QTL information for the F1 population was integrated using Mapchart software (Voorrips 2002) to determine the total number of leaf trait-related QTLs.

\section{Results}

Phenotypic data analysis

Extensive phenotypic variations were observed for all the measured quantitative traits in this alfalfa leaf traits, as shown by the descriptive statistics in Table 1 . The range of values for F1 plants was wider than that of the parents, reflecting the presence of transgressive segregation. The kurtosis and skewness of leaf traits were close to zero. The coefficient of genetic variation ranged from 0.14 for LL in 2016 to 0.36 for LA in 2017 (Table 1). Broad-sense heritability $\left(H^{2}\right)$ was calculated as described in a previous study (Tornqvist et al. 2018). Our finding broad-sense heritability ranged from 0.41 to 0.66 . Correlation analysis showed a significant correlation according to Pearson's test $(P<0.01)$ among four yield-related traits (Table 2). In 2016, 2017, and 2018, the correlation coefficients for LL and LA were 0.8 , 0.57 , and 0.62 , respectively; those for LA and LW were $0.87,0.61$, and 0.79 , respectively; and those for LL and LW were $0.43,0.31$, and 0.37 , respectively. Genotypic variation, variation between years and genotype $\times$ year interactions were significant for all leaf-related traits $(P<0.001)$ (Table 3). As can be seen from the probability density distribution in Fig. 1, the difference in leaf traits between the two parents was significant $(P<$ 0.01 ). The leaf sizes of female parent were obviously smaller than that of the maternal parent. 

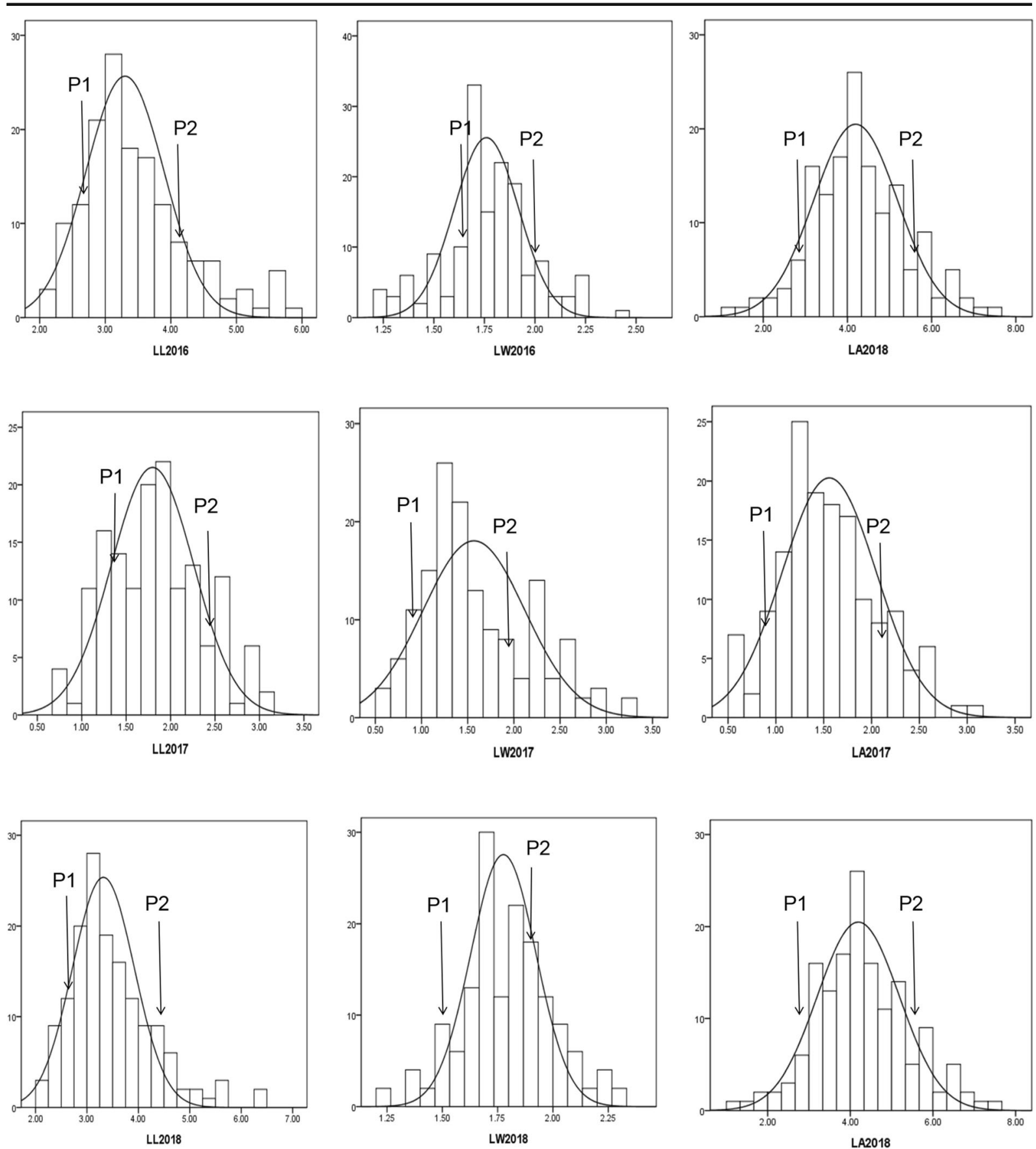

Fig. 1 Distribution of quantitative traits in the Medicago sativa L. F1 population. Arrows indicate the mean values of the two parents. P1 stands for the female parent and P2 stands for the maternal parent

Identification of QTLs for leaf-related traits

We performed interval mapping for LA, LL, and LW using the phenotypic data of 2016, 2017, and 2018 (Tables 4, 5, and 6). A total of 60 leaf size-related QTLs were identified over the 3-year experiment, and these QTLs were distributed for chromosomes 1 to 8 . The percent phenotypic variance explained by individual QTLs ranged from 2.99 to $18.78 \%$, with 13 QTLs each accounting for more than $10 \%$ of the phenotypic 
Table 4 Quantitative trait loci (QTL) parameters in the Medicago sativa L. leaf length traits

\begin{tabular}{|c|c|c|c|c|c|c|c|c|c|c|}
\hline Parent & Trait name ${ }^{\mathrm{a}}$ & QTL & $\mathrm{LG}^{\mathrm{b}}$ & $\begin{array}{l}\text { Position }^{\mathrm{c}} \\
(\mathrm{cM})\end{array}$ & $\begin{array}{l}\text { LOD interval } \\
(\mathrm{cM})\end{array}$ & $\begin{array}{l}\text { Left } \\
\text { marker }\end{array}$ & $\begin{array}{l}\text { Right } \\
\text { marker }\end{array}$ & $\operatorname{LOD}^{d}$ & $\begin{array}{l}\text { PVE } \\
(\%)^{\mathrm{e}}\end{array}$ & $\operatorname{Add}^{\mathrm{f}}$ \\
\hline \multirow[t]{3}{*}{ Paternal } & $\begin{array}{c}\text { 2016-leaf } \\
\text { length }\end{array}$ & qLL-1 & $3 \mathrm{C}$ & 90.5 & $89.65-91.77$ & TP16142 & TP28355 & 2.8213 & 5.0925 & 0.2906 \\
\hline & $\begin{array}{c}\text { 2018-leaf } \\
\text { length }\end{array}$ & qLL-2 & $2 \mathrm{C}$ & 81.0 & $80.4-81.1$ & TP11421 & TP102553 & 2.7998 & 6.2817 & -0.2555 \\
\hline & $\begin{array}{c}\text { 2018-leaf } \\
\text { length }\end{array}$ & qLL-3 & $2 \mathrm{D}$ & 32.0 & $30.41-34.97$ & TP5760 & ТР66523 & 3.6489 & 8.9753 & -0.3031 \\
\hline \multirow[t]{7}{*}{ Maternal } & $\begin{array}{c}\text { 2016-leaf } \\
\text { length }\end{array}$ & qLL-4 & $1 \mathrm{~B}$ & 120.0 & $119.34-120.73$ & TP119651 & ТР96230 & 3.4626 & 18.775 & -0.2342 \\
\hline & $\begin{array}{c}\text { 2016-leaf } \\
\text { length }\end{array}$ & qLL-5 & $2 \mathrm{D}$ & 7.5 & $6.32-12.51$ & TP116788 & ТР49959 & 5.049 & 7.5305 & -0.1482 \\
\hline & $\begin{array}{c}\text { 2016-leaf } \\
\text { length }\end{array}$ & qLL-6 & $4 \mathrm{~B}$ & 73.5 & $73.5-73.8$ & ТР92963 & TP121286 & 4.2618 & 5.4382 & 0.1253 \\
\hline & $\begin{array}{c}\text { 2016-leaf } \\
\text { length }\end{array}$ & qLL-7 & $6 \mathrm{~B}$ & 98.0 & $97.01-98.78$ & ТР59911 & TP112047 & 2.5053 & 3.1423 & -0.0973 \\
\hline & $\begin{array}{c}\text { 2017-leaf } \\
\text { length }\end{array}$ & qLL-8 & $6 \mathrm{~A}$ & 122.0 & $121.85-123.21$ & ТР54361 & ТР12469 & 2.6659 & 9.2553 & 0.2711 \\
\hline & $\begin{array}{c}\text { 2018-leaf } \\
\text { length }\end{array}$ & qLL-9 & $1 \mathrm{D}$ & 35.5 & $33.54-37.11$ & TP5157 & TP100870 & 2.586 & 6.4935 & -0.2392 \\
\hline & $\begin{array}{c}\text { 2018-leaf } \\
\text { length }\end{array}$ & qLL-10 & $4 \mathrm{C}$ & 114.0 & $113.61-115.77$ & TP13043 & ТР40661 & 3.1843 & 11.110 & 0.3083 \\
\hline
\end{tabular}

a The leaf traits described in the "Materials and methods"

${ }^{\mathrm{b}}$ Chromosomal position

${ }^{\mathrm{c}}$ The genetic distance of the QTL on the relevant chromosome in the genetic linkage map

${ }^{\mathrm{d}}$ The threshold LOD values determined with 1000 permutations of the data

${ }^{\mathrm{e}}$ The proportion of phenotypic variation explained by each QTL

${ }^{\mathrm{f}}$ Estimated additive effect of the QTL

variation explained (PVE). There were 27 QTLs related to LA, 10 QTLs related to LL, and 23 QTLs related to LW.

Identification of leaf length QTLs in the $\mathrm{F}_{1}$ population

Table 4 lists QTL for LL leaf traits identified by CIM in 3 years and combined over years. These QTLs were located on chromosomes 1B, 1D, 2C, 2D, 3C, 4B, 4C, $6 \mathrm{~A}$, and $6 \mathrm{~B}$, and the phenotypic variance explained by the individual QTLs ranged from $3.14 \%$ to $18.77 \%$ (Table 4). QTLs on chromosomes 4C and 1B contributed $11.11 \%$ and $18.78 \%$ in 2016 and 2018 , respectively, to the phenotypic variation. A QTL accounting for $18.78 \%$ of the total variation was detected on chromosome 1B within the marker interval TP119651TP96230. Another QTL mapping to 4C within TP13043-TP40661 accounted for $11.11 \%$ of the total phenotypic variation. In addition, contrary to QTL in
$1 \mathrm{~B}, 1 \mathrm{D}, 2 \mathrm{C}, 2 \mathrm{D}$, and $6 \mathrm{~B}$ had negative effects $($ add $<0)$ on LA (Table 4).

Identification of leaf width QTLs in the $\mathrm{F}_{1}$ population

A total of 23 QTLs related to LW (38.3\% of all leaf sizerelated QTLs) were identified in the 3 years of the experiment, and these QTLs were mapped to chromosomes 1B, 1D, 2A, 2C, 2D, 3A, 3B, 3C, 4B, 4C, 4D, $5 \mathrm{~A}, 6 \mathrm{~B}, 6 \mathrm{D}, 7 \mathrm{~A}$, and $8 \mathrm{~A}$ (Table 5). The phenotypic variance explained by individual QTLs ranged from 2.99 to $14.07 \%$. Seven QTLs on chromosomes 3B, $3 \mathrm{C}, 4 \mathrm{~B}, 4 \mathrm{D}, 6 \mathrm{~B}$, and $8 \mathrm{~A}$ explained more than $10 \%$ of the phenotypic variation, with genetic contribution rates ranging from 10.76 to $14.07 \%$ (PVE). The QTLs on chromosomes 4C, 6B, 6D, and 8A were identified in multiple years, suggesting they have a greater impact on LW (6.47-12.93\%). QTL impact analysis showed that $30.43 \%(7 / 23)$ of the QTLs were associated with increased LW, indicating different allelic effects. 
Table 5 Quantitative trait loci (QTL) parameters in the Medicago sativa $\mathrm{L}$. leaf width traits

\begin{tabular}{|c|c|c|c|c|c|c|c|c|c|c|}
\hline Parent & Trait Name ${ }^{a}$ & QTL & $L G^{b}$ & $\begin{array}{l}\text { Position }^{\mathrm{c}} \\
(\mathrm{cM})\end{array}$ & $\begin{array}{l}\text { LOD interval } \\
(\mathrm{cM})\end{array}$ & $\begin{array}{l}\text { Left } \\
\text { marker }\end{array}$ & $\begin{array}{l}\text { Right } \\
\text { marker }\end{array}$ & $\operatorname{LOD}^{\mathrm{d}}$ & $\begin{array}{l}\text { PVE } \\
(\%)^{\mathrm{e}}\end{array}$ & $\operatorname{Add}^{\mathrm{f}}$ \\
\hline \multirow[t]{6}{*}{ Paternal } & $\begin{array}{l}\text { 2016-leaf } \\
\text { width }\end{array}$ & qLW-1 & $2 \mathrm{C}$ & 107.0 & $106.18-108.11$ & ТР118790 & ТР43156 & 3.7836 & 8.5875 & -0.1335 \\
\hline & $\begin{array}{c}\text { 2016-leaf } \\
\text { width }\end{array}$ & qLW-2 & $6 \mathrm{~B}$ & 70.0 & $67.66-75.32$ & SSR44 & TP51277 & 4.3961 & 12.801 & -0.1629 \\
\hline & $\begin{array}{c}\text { 2017-leaf } \\
\text { width }\end{array}$ & qLW-3 & $8 \mathrm{~A}$ & 18.0 & $17.56-19.16$ & TP111076 & ТP2146 & 4.2782 & 5.5656 & -0.2268 \\
\hline & $\begin{array}{c}\text { 2017-leaf } \\
\text { width }\end{array}$ & qLW-4 & $8 \mathrm{~A}$ & 90.0 & $88.36-90.15$ & ТР26454 & ТР82500 & 3.839 & 10.806 & 0.3123 \\
\hline & $\begin{array}{c}\text { 2018-leaf } \\
\text { width }\end{array}$ & qLW-5 & $3 \mathrm{~A}$ & 52.0 & $51.67-53.01$ & TP38054 & ТР73336 & 2.5706 & 8.7284 & -0.0841 \\
\hline & $\begin{array}{c}\text { 2018-leaf } \\
\text { width }\end{array}$ & qLW-6 & $3 \mathrm{~B}$ & 89.0 & $87.30-89.91$ & ТР68289 & ТP70313 & 4.4533 & 11.475 & -0.0967 \\
\hline \multirow[t]{17}{*}{ Maternal } & $\begin{array}{c}\text { 2016-leaf } \\
\text { width }\end{array}$ & qLW-7 & $1 \mathrm{~B}$ & 56.75 & $56.73-56.79$ & ТР20480 & TP13207 & 5.1418 & 4.5248 & -0.0748 \\
\hline & $\begin{array}{c}\text { 2016-leaf } \\
\text { width }\end{array}$ & qLW-8 & $1 \mathrm{D}$ & 39.0 & $38.72-39.53$ & TP124060 & ТР95981 & 3.521 & 2.9864 & 0.061 \\
\hline & $\begin{array}{c}\text { 2016-leaf } \\
\text { width }\end{array}$ & qLW-9 & $2 \mathrm{D}$ & 53.0 & $50.10-55.74$ & TP106191 & TP15553 & 4.906 & 5.4625 & -0.0836 \\
\hline & $\begin{array}{c}\text { 2016-leaf } \\
\text { width }\end{array}$ & qLW-10 & $4 \mathrm{~B}$ & 116.0 & $115.18-116.58$ & ТР65847 & ТР44955 & 11.174 & 10.757 & 0.116 \\
\hline & $\begin{array}{c}\text { 2016-leaf } \\
\text { width }\end{array}$ & qLW-11 & $4 \mathrm{C}$ & 50.0 & $50.21-50.93$ & ТP17099 & ТР62659 & 4.7755 & 4.2022 & -0.0725 \\
\hline & $\begin{array}{c}\text { 2016-leaf } \\
\text { width }\end{array}$ & qLW-12 & $6 \mathrm{~B}$ & 113.0 & $111.45-115.42$ & ТР92765 & ТР77093 & 7.1692 & 6.4695 & -0.0908 \\
\hline & $\begin{array}{c}\text { 2016-leaf } \\
\text { width }\end{array}$ & qLW-13 & $7 \mathrm{~A}$ & 25.0 & $24.07-25.21$ & TP11839 & TP78641 & 5.4747 & 5.2899 & -0.0821 \\
\hline & $\begin{array}{c}\text { 2016-leaf } \\
\text { width }\end{array}$ & qLW-14 & $8 \mathrm{~A}$ & 35.0 & $34.89-35.93$ & ТР60448 & TP35978 & 8.3551 & 7.7281 & 0.0984 \\
\hline & $\begin{array}{c}\text { 2016-leaf } \\
\text { width }\end{array}$ & qLW-15 & $8 \mathrm{~A}$ & 43.5 & $43.22-43.74$ & ТР99687 & ТР27214 & 13.021 & 12.927 & -0.1264 \\
\hline & $\begin{array}{c}\text { 2017-leaf } \\
\text { width }\end{array}$ & qLW-16 & $4 \mathrm{C}$ & 109.5 & $109.47-109.86$ & TP32203 & TP25090 & 3.5918 & 6.2304 & 0.1851 \\
\hline & $\begin{array}{c}\text { 2017-leaf } \\
\text { width }\end{array}$ & qLW-17 & $4 \mathrm{D}$ & 22.0 & $21.59-22.91$ & TP125366 & ТР68765 & 6.2212 & 12.305 & -0.2579 \\
\hline & $\begin{array}{c}\text { 2017-leaf } \\
\text { width }\end{array}$ & qLW-18 & $4 \mathrm{D}$ & 56.5 & $56.25-56.63$ & ТР40032 & ТР11560 & 3.181 & 6.5066 & 0.1887 \\
\hline & $\begin{array}{l}\text { 2017-leaf } \\
\text { width }\end{array}$ & qLW-19 & $5 \mathrm{~A}$ & 94.0 & $94.69-94.71$ & ТР19012 & TP7685 & 3.3289 & 7.778 & 0.2064 \\
\hline & $\begin{array}{c}\text { 2017-leaf } \\
\text { width }\end{array}$ & qLW-20 & $6 \mathrm{D}$ & 115.5 & $113.20-119.16$ & TP32265 & ТР34930 & 2.7874 & 4.7817 & -0.1603 \\
\hline & $\begin{array}{l}\text { 2018-leaf } \\
\text { width }\end{array}$ & qLW-21 & $2 \mathrm{~A}$ & 64.0 & $63.90-65.82$ & TP22321 & TP89578 & 3.302 & 6.7458 & 0.0733 \\
\hline & $\begin{array}{c}\text { 2018-leaf } \\
\text { width }\end{array}$ & qLW-22 & $3 \mathrm{C}$ & 26.0 & $25.64-27.47$ & TP125264 & TP105519 & 5.6692 & 14.070 & -0.104 \\
\hline & $\begin{array}{c}\text { 2018-leaf } \\
\text { width }\end{array}$ & qLW-23 & $6 \mathrm{D}$ & 60.0 & $58.42-63.33$ & TP58492 & ТР89224 & 3.1298 & 6.3514 & -0.0699 \\
\hline
\end{tabular}

Identification of QTLs for leaf area in the F1 population

Twenty-seven QTLs were detected for LA chromosomes 1-8(Table 4), and together, they contributed $45 \%$ of the phenotypic variation (individual variance ranged from 3.41 to $18.56 \%$ ). The LOD values ranged between 2.67 and 9.26, and the additive effect values ranged between -0.52 and 0.96 . The QTLs on chromosomes $1 \mathrm{~A}, 1 \mathrm{C}, 2 \mathrm{D}, 3 \mathrm{~B}, 4 \mathrm{C}$, and $5 \mathrm{~B}$ were identified in multiple years, and these QTLs had a large effect on LA (4.03 to $13.97 \%$ ). Among these QTLs, the QTL on chromosome 4B explained the largest amount of 
Table 6 Quantitative trait loci (QTL) parameters in the Medicago sativa L. leaf area traits

\begin{tabular}{|c|c|c|c|c|c|c|c|c|c|c|}
\hline Parent & Trait Name ${ }^{a}$ & QTL & $\mathrm{LG}^{\mathrm{b}}$ & Position $^{\mathrm{c}}(\mathrm{cM})$ & LOD interval (cM) & Left marker & Right marker & $\operatorname{LOD}^{\mathrm{d}}$ & $\operatorname{PVE}(\%)^{\mathrm{e}}$ & $\operatorname{Add}^{\mathrm{f}}$ \\
\hline \multirow[t]{9}{*}{ Paternal } & 2016-leaf area & qLA-1 & $5 \mathrm{~B}$ & 24.0 & $23.70-24.29$ & ТР90528 & TP111237 & 2.7998 & 8.1377 & -0.2519 \\
\hline & 2017-leaf area & qLA-2 & $1 \mathrm{~A}$ & 97.0 & $96.59-97.47$ & ТР6437 & ТP24150 & 3.9881 & 1.1253 & 0.9401 \\
\hline & 2017-leaf area & qLA-3 & $1 \mathrm{~A}$ & 98.0 & $97.47-98.72$ & TP24150 & ТР60413 & 4.1613 & 1.1267 & 0.9486 \\
\hline & 2017-leaf area & qLA-4 & $2 \mathrm{~B}$ & 99.0 & $97.41-99.25$ & TP31503 & ТР69543 & 4.0438 & 1.1247 & 0.9612 \\
\hline & 2017-leaf area & qLA-5 & $8 \mathrm{D}$ & 75.0 & 72.76-77.09 & TP110657 & TP118899 & 3.3673 & 1.1033 & 0.9335 \\
\hline & 2018-leaf area & qLA-6 & $2 \mathrm{C}$ & 82.0 & $81.11-84.58$ & TP11421 & TP102553 & 2.9911 & 5.0939 & -0.3161 \\
\hline & 2018-leaf area & qLA-7 & $2 \mathrm{D}$ & 32.0 & $30.41-34.97$ & TP5760 & ТР66523 & 5.046 & 8.7522 & -0.4093 \\
\hline & 2018-leaf area & qLA-8 & $3 \mathrm{~A}$ & 52.0 & $51.67-53.01$ & TP38054 & ТР73336 & 2.9029 & 7.1781 & -0.3771 \\
\hline & 2018-leaf area & qLA-9 & $3 \mathrm{~B}$ & 91.5 & 89.91-93.02 & TP70313 & ТР49598 & 6.283 & 13.966 & -0.5222 \\
\hline \multirow[t]{18}{*}{ Maternal } & 2016-leaf area & qLA-10 & $1 \mathrm{C}$ & 47.5 & $47.08-48.02$ & ТР91677 & TP105407 & 5.1591 & 5.1207 & -0.209 \\
\hline & 2016-leaf area & qLA-11 & $2 \mathrm{D}$ & 53.0 & $50.10-55.74$ & TP106191 & TP15553 & 5.3046 & 5.5166 & -0.219 \\
\hline & 2016-leaf area & qLA-12 & $3 \mathrm{D}$ & 69.0 .0 & $68.61-69.55$ & ТР57248 & TP8555 & 3.5987 & 3.4814 & -0.1723 \\
\hline & 2016-leaf area & qLA-13 & $4 \mathrm{~B}$ & 116.0 & $115.18-116.58$ & ТР65847 & TP44955 & 9.2568 & 18.564 & 0.3939 \\
\hline & 2016-leaf area & qLA-14 & $4 \mathrm{C}$ & 50.5 & $50.21-50.93$ & ТP17099 & ТР62659 & 3.816 & 4.0314 & -0.1849 \\
\hline & 2016-leaf area & qLA-15 & $4 \mathrm{D}$ & 88.5 & $88.22-88.85$ & TP103833 & ТР77009 & 4.4514 & 6.3862 & -0.2316 \\
\hline & 2016-leaf area & qLA-16 & $5 \mathrm{~A}$ & 23.0 & $22.14-23.32$ & TP103349 & ТР20782 & 4.8877 & 5.0186 & -0.2053 \\
\hline & 2016-leaf area & qLA-17 & $6 \mathrm{~A}$ & 130.0 & $128.32-133.14$ & TP20995 & TP37415 & 3.5105 & 3.4125 & 0.1732 \\
\hline & 2016-leaf area & qLA-18 & $6 \mathrm{C}$ & 50.0 & $48.49-50.23$ & ТР80549 & TP108406 & 3.9436 & 5.7398 & 0.2223 \\
\hline & 2016-leaf area & qLA-19 & $8 \mathrm{~A}$ & 49.5 & $49.04-50.06$ & TP59420 & TP53438 & 5.1641 & 6.0708 & -0.2267 \\
\hline & 2017-leaf area & qLA-20 & $5 \mathrm{~B}$ & 98.0 & $97.40-98.48$ & ТР49465 & SSR50 & 2.9843 & 10.029 & -0.2879 \\
\hline & 2018-leaf area & qLA-21 & $1 \mathrm{C}$ & 135.0 & $133.90-136.04$ & ТР60798 & ТР8894 & 6.8395 & 8.5581 & 0.4222 \\
\hline & 2018-leaf area & qLA-22 & $2 \mathrm{~B}$ & 126.5 & $125.59-127.18$ & ТР61589 & TP123947 & 4.9804 & 6.0729 & -0.3538 \\
\hline & 2018-leaf area & qLA-23 & $3 \mathrm{~B}$ & 65.0 & $64.61-65.47$ & ТР19780 & ТР27949 & 3.8772 & 6.3491 & -0.3609 \\
\hline & 2018-leaf area & qLA-24 & $3 \mathrm{C}$ & 5.5 & $4.55-7.23$ & TP70173 & ТР66342 & 2.6724 & 3.4219 & -0.2667 \\
\hline & 2018-leaf area & qLA-25 & $4 \mathrm{C}$ & 39.5 & $39.25-39.97$ & ТP106798 & ТP68992 & 4.3787 & 5.2694 & -0.3278 \\
\hline & 2018-leaf area & qLA-26 & $6 \mathrm{D}$ & 53.0 & $51.70-54.13$ & ТР62599 & ТР69225 & 8.1678 & 13.172 & -0.5249 \\
\hline & 2018-leaf area & qLA-27 & $7 \mathrm{D}$ & 105.0 & $104.3-105.91$ & ТР96019 & TP12903 & 6.685 & 8.4479 & 0.4162 \\
\hline
\end{tabular}

phenotypic variance (18.56\%). QTLs on chromosomes 3B, 5B, and 6D between marker intervals TP70313TP49598, TP65847-TP44955, and TP699-TP69225, respectively, also explained a large amount of phenotypic variance $(13.97 \%, 10.03 \%$, and $13.17 \%$, respectively).

Analysis of QTL mapping results

A total of six QTLs were identified in the same location in all 3 years (Figs. 2 and 3). It can be seen from the QTL map of the female parent plant (Fig. 2) that two QTLs associated with LA and two associated with LL were mapped to the same location on 2C and 2D in 2018 (8 $9 \mathrm{cM}$ and $52 \mathrm{cM}$ ). These QTLs had LOD values ranging from 2.79 to 2.99 . The percent phenotypic variance explained by the individual QTLs ranged from
5.09 to $6.28 \%$, and the additive effect ranged between 0.31 and -0.25 . Two QTLs related to LW and LA were detected on chromosome $3 \mathrm{~A}$ in $2018(64 \mathrm{cM})$. The LOD values ranged from 2.57 to 2.90 , and the percent phenotypic variation explained ranged from $7.18 \%$ to $8.73 \%$. QTLs for LW and LA were mapped to the same position on chromosome 2D in 2016 (119 cM)(Fig. 2). QTLs for LA and LW were also mapped to the same location on chromosomes $4 \mathrm{~B}$ and $4 \mathrm{C}$ (70 $\mathrm{cM}$ and $101 \mathrm{cM}$, respectively).

\section{Discussion}

The two parental lines used for creating the mapping population varied in leaf-related trait phenotypes 
1A

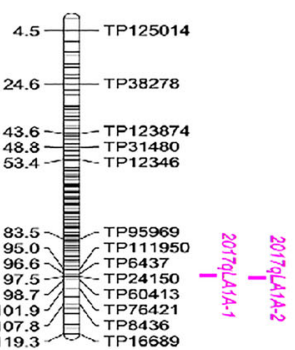

3B

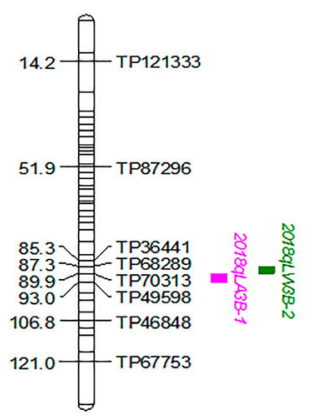

2B

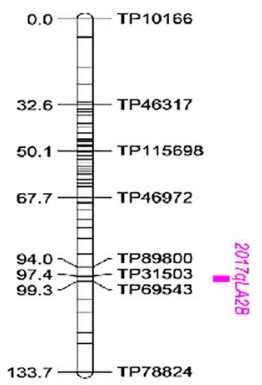

3C

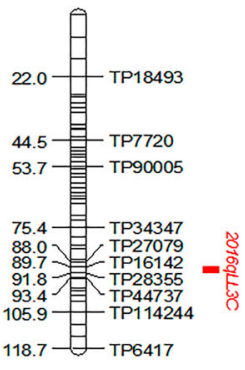

2C

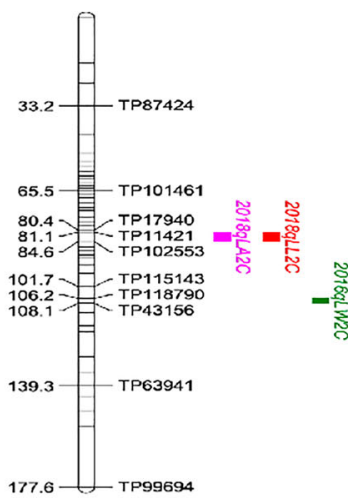

$5 B$
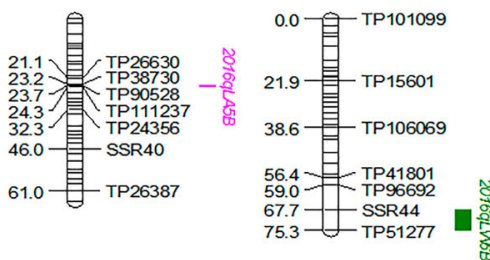

2D

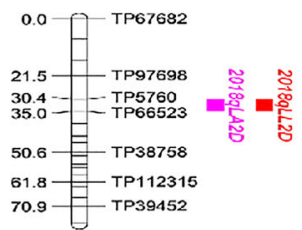

Fig. 2 Locations of leaf trait QTLs on the constructed paternal linkage map

(Table 1), and there was variation in these traits in our population. Leaf size has been reported to be highly heritable (Caradus and Chapman 1996). Previous study found that the broad-sense heritability of LA in $M$. truncatula $L$. is 0.45 , which is significantly less than the heritability of 0.66 that we observed (Avia et al.
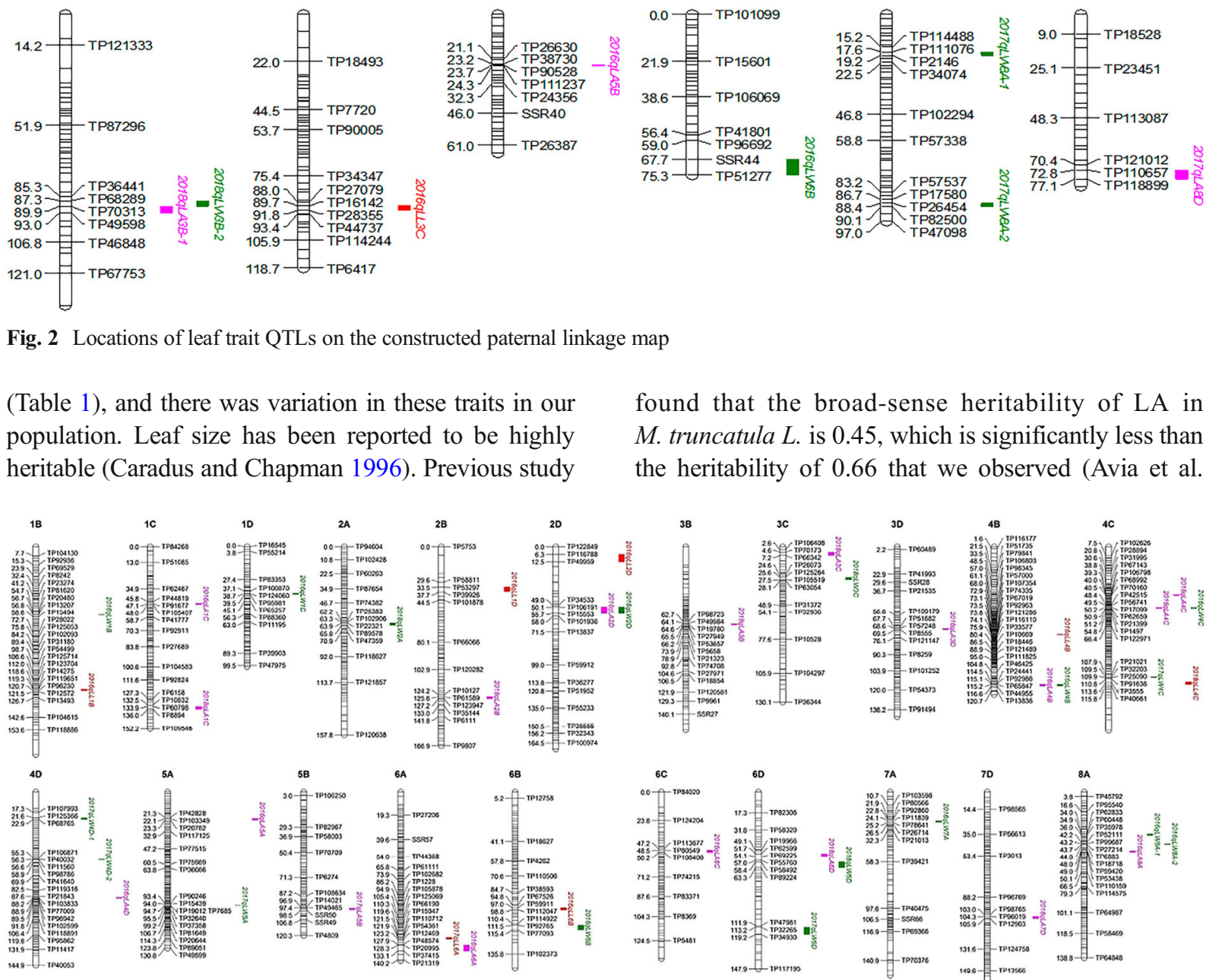

Fig. 3 Locations of leaf trait QTLs on the constructed maternal linkage map 
2013). We also found that there was a high correlation between LL, LW, and LA, which is the same as in previous studies (Avia et al. 2013; Badri et al. 2011; Cogan et al. 2006). There was also a positive correlation between leaf traits measured over 3 years, and they are dependent on environmental changes. This change may be due to differences in heredity caused by differences between climated or the environment in which they are located. We observed a genotype $\times$ year interaction. It can be seen from the results that leaf traits are clearly influenced by environmental factors; therefore, selecting markers from QTLs that have similar effect sizes across different years will be necessary to efficiently breed alfalfa.

Comparison of QTL associated with leaf-related traits in alfalfa

We have identified 60 major QTLs affecting LL, LW, and LA in this population, and the QTLs discovered include new ones that have not been previously identified. In this study, QTLs for LA, LL, and LW were identified by first looking for significant linkages between SNP markers, and then CIM analysis was performed to predict more precise genomic locations for each QTL. Some alfalfa QTLs have been reported for winter injury and fall dormancy, but the QTL intervals were large $(>10 \mathrm{cM})(\mathrm{Li}$ et al. 2015b), and thus there is need for further research to narrow down the QTL positions, using SDA markers and the composite interval mapping method, and QTL intervals were greatly reduced $(<3 \mathrm{cM})$ in the present analysis. In our study, we found 27 QTLs controlling LA, and four QTLs with a heritability greater than $10 \%$ were mapped in qLA-9, qLA-13, qLA-20, and qLA-26; the locations of these QTLs are consistent with those identified in previous studies (Foroozanfar et al. 2014; Moreau et al. 2012).

To reduce the effect of the interaction between genetics and the environment $(\mathrm{G} \times \mathrm{E})$, we used BLUP to estimate phenotypic variation across three traits and identified QTL for each trait analyzed in this study. Most QTLs identified in the present study were co-located with previously reported yield-related QTL (Zhang et al. 2019) and fall dormancy QTL (Li et al. 2015b). Their mapping results are consistent with those of this study and provide further evidence that the corresponding QTLs in alfalfa may be important for the control of LA in alfalfa. In addition, we identified 23 QTLs controlling LW in the alfalfa population, and seven major
QTLs were distributed on chromosomes 3B, 3C, 4B, $4 \mathrm{D}, 6 \mathrm{~B}$, and $8 \mathrm{~A}$. We compared the physical locations of these QTLs with those of published QTLs locations. We found major QTL loci on qLW-15 and qLW-22, located at $43.5 \mathrm{cM}$ and $26 \mathrm{cM}$ on chromosomes 4 and 8 , which is consistent with the sites previously found in winter hardiness (40.8-43.6 cM) (Adhikari et al. 2018). LW QTLs on alfalfa chromosomes 4 and 6 have not been previously found and may represent new QTLs. We found several QTLs (qLA-11, qLW-9, qLA-13, qLW10, qLA-14, qlw-11, qLA-6, qLL-2, qLA-7, qLL-3, qLW-5, and qLA-8) identified at the same location, which have been identified for many years and have a large contribution rate; these QTLs may play a major role in controlling leaf traits. We also identified ten novel QTLs for LL, and none of the previously reported QTLs were found in chromosome 1, 2, 3, 4, and 6. Therefore, we not only identified stable QTLs identified by other studies but also identified some novel QTLs, further illustrating the complexity of the genetic architecture that controls leaf trait.

Given that the average heritability $(52 \%)$ of leafrelated traits was reasonable for genetic analysis, the QTL identified in the present analysis need further validation. According to the results obtained over 3 years, it can be speculated that there are large-effect, stable, and reliable leaf size-related QTLs that play an important role in controlling leaf-related traits; their PVE is higher than $10 \%$ (qLL-1, qLL-4, qLW-3, qLW-4, qLW-6, qLW8, qLA-3, qLA-4, qLA-5, qLA-6). These stable QTLs may be useful for breeding alfalfa with altered leaf size. We also identified novel QTLs, which provide new target genomic regions for further identification of alfalfa genes regulating leaf traits. Furthermore, in the present analysis, we were able to narrow down the QTL interval with high PVE, which will facilitate further investigations such as fine mapping and gene cloning.

Acknowledgments The authors express their appreciation to the reviewers for their valuable comments on this manuscript.

Author contribution Tiejun Zhang and Qingchuan Yang designed the experiments and developed the mapping population. Fei He and Junmei Kang performed data analysis and wrote the manuscript. Fan Zhang, Ruicai Long, and Long-Xi Yu performed the genotyping and sequencing and constructed genetic maps. Zhen Wang and Zhongxiang Zhao managed field work and investigated phenotypic data. All the authors read and approved the final manuscript. 
Funding information This work was supported by Breeding forage and grain legumes to increase China's and EU's protein self-sufficiency, collaborative research key project between China and EU, granted by the Ministry of Science and Technology of China (2017YFE0111000/EUCLEG 727312), the National Natural Science Foundation of China (No. 31772656), the China Forage and Grass Research System (CARS-34), and the Agricultural Science and Technology Innovation Program (ASTIP-IAS14).

\section{Compliance with ethical standards}

Conflict of interest The authors declare that they have no conflict of interest.

Open Access This article is distributed under the terms of the Creative Commons Attribution 4.0 International License (http:// creativecommons.org/licenses/by/4.0/), which permits unrestricted use, distribution, and reproduction in any medium, provided you give appropriate credit to the original author(s) and the source, provide a link to the Creative Commons license, and indicate if changes were made.

\section{References}

Adhikari L, Lindstrom OM, Markham J, Missaoui AM (2018) Dissecting key adaptation traits in the polyploid perennial Medicago sativa using GBS-SNP mapping. Front Plant Sci 9(3):934-939

Arraouadi S, Chardon F, Huguet T, Aouani ME, Badri M (2011) QTLs mapping of morphological traits related to salt tolerance in Medicago truncatula. Acta Physiol Plant 33(3):917926

Avia K, Pilet-Nayel M-L, Bahrman N, Baranger A, Delbreil B, Fontaine V, Hamon C, Hanocq E, Niarquin M, Sellier H (2013) Genetic variability and QTL mapping of freezing tolerance and related traits in Medicago truncatula. Theor Appl Genet 126(9):2353-2366

Badri M, Huguet T, Aouani ME (2011) Quantitative trait loci associated with drought tolerance in the model legume Medicago truncatula. Euphytica 181(3):415-428

Bhagsari AS (1990) Photosynthetic evaluation of sweet potato germplasm. J Am Soc Hortic Sci 115(4):634-639

Cai H, Chu Q, Yuan L, Liu J, Chen X, Chen F, Mi G, Zhang F (2012) Identification of quantitative trait loci for leaf area and chlorophyll content in maize (Zea mays) under low nitrogen and low phosphorus supply. Mol Breed 30(1):251-266

Caradus J, Chapman D (1996) Selection for and heritability of stolon characteristics in two cultivars of white clover. Crop Sci 36(4):900-904

Chitwood DH, Headland LR, Filiault DL, Kumar R, Jiménezgómez JM, Schrager AV, Park DS, Peng J, Sinha NR, Maloof JN (2012a) Native environment modulates leaf size and response to simulated foliar shade across wild tomato species. PLoS One 7(1):e29570
Chitwood DH, Headland LR, Kumar R, Peng J, Maloof JN, Sinha NR (2012b) The developmental trajectory of leaflet morphology in wild tomato species. Plant Physiol 158(3):1230-1240

Chitwood DH, Headland LR, Ranjan A, Martinez CC, Braybrook SA, Koenig DP, Kuhlemeier C, Smith RS, Sinha NR (2012c) Leaf asymmetry as a developmental constraint imposed by auxin-dependent phyllotactic patterning. Plant Cell 24(6): 2318-2327

Cogan NOI, Abberton MT, Smith KF, Kearney G, Marshall AH, Williams A, Michaelson-Yeates TPT, Bowen C, Jones ES, Vecchies AC (2006) Individual and multi-environment combined analyses identify QTLs for morphogenetic and reproductive development traits in white clover ( Trifolium repens L.). Theor Appl Genet 112(8):1401-1415

Cui K, Peng S, Xing Y, Yu S, Xu C, Zhang Q (2003) Molecular dissection of the genetic relationships of source, sink and transport tissue with yield traits in rice. Theor Appl Genet 106(4):649-658

Dias PMB, Brunelmuguet S, Dürr C, Huguet T, Demilly D, Wagner MH, Teulatmerah B (2011) QTL analysis of seed germination and pre-emergence growth at extreme temperatures in Medicago truncatula. Theor Appl Genet 122(2):429444

Feng T, Bradbury PJ, Brown PJ, Hsiaoyi H, Qi S, Sherry FG, Rocheford TR, Mcmullen MD, Holland JB, Buckler ES (2015)Genome-wide association study of leaf architecture in the maize nested association mapping population. Nat Genet 43(2):159-162

Foroozanfar M, Exbrayat S, Gentzbittel L, Bertoni G, Maury P, Naghavie MR, Peyghambari A, Badri M, Ben C, Debelle F (2014) Genetic variability and identification of quantitative trait loci affecting plant growth and chlorophyll fluorescence parameters in the model legume Medicago truncatula under control and salt stress conditions. Funct Plant Biol 41(9): 983-1001

Hou X, Liu Y, Xiao Q, Wei B, Zhang X, Yong G, Wang Y, Jiang C, $\mathrm{Hu}$ Y, Liu H (2015) Genetic analysis for canopy architecture in an F2:3 population derived from two-type foundation parents across multi-environments. Euphytica 205(2):421440

Ishimaru K, Yano M, Aoki N, Ono K, Hirose T, Lin SY, Monna L, Sasaki T, Ohsugi R (2001) Toward the mapping of physiological and agronomic characters on a rice function map: QTL analysis and comparison between QTLs and expressed sequence tags. Theor Appl Genet 102(6-7):793-800

Jia H, Wan H, Yang S, Zhang Z, Kong Z, Xue S, Zhang L, Ma Z (2013) Genetic dissection of yield-related traits in a recombinant inbred line population created using a key breeding parent in China's wheat breeding. Theor Appl Genet 126(8): 2123-2139

Kobayashi S, Fukuta Y, Yagi T, Sato T, Osaki M, Khush GS (2004) Identification and characterization of quantitative trait loci affecting spikelet number per panicle in rice (Oryza sativa L.). Field Crop Res 89(2):253-262

Ku L, Zhang J, Zhang JC, Guo S, Liu H, Zhao R, Yan Q, Chen Y (2012) Genetic dissection of leaf area by jointing two F2\&emsp;:\&emsp;3 populations in maize (Zea Mays L.). Plant Breed 131(5):591-599

Lei M, Li H, Zhang L, Wang J (2015) QTL IciMapping:integrated software for genetic linkage map construction and 
quantitative trait locus mapping in biparental populations. Crop J 3(3):269-283

Li C, Li Y, Shi Y, Song Y, Zhang D, Buckler ES, Zhang Z, Wang T, Li Y (2015a) Genetic control of the leaf angle and leaf orientation value as revealed by ultra-high density maps in three connected maize populations. PLoS One 10(3): $\mathrm{e} 0121624$

Li X, Alarcónzúñiga B, Kang J, Tahir MHN, Jiang Q, Wei Y, Reyno R, Robins JG, Brummer EC (2015b) Mapping fall dormancy and winter injury in tetraploid alfalfa. J Physiol 55(5):851-858

Lieth JH, Reynolds JF, Rogers HH (1986) Estimation of leaf area of soybeans grown under elevated carbon dioxide levels. Field Crop Res 13(3):193-203

Lu F, Lipka AE, Glaubitz J, Elshire R, Cherney JH, Casler MD, Buckler ES, Costich DE (2013) Switchgrass genomic diversity, ploidy, and evolution: novel insights from a networkbased SNP discovery protocol. PLoS Genet 9(1):e1003215

Mansur LM, Lark KG, Kross H, Oliveira A (1993) Interval mapping of quantitative trait loci for reproductive, morphological, and seed traits of soybean (Glycine max L.). Theor Appl Genet 86(8):907-913

Moreau D, Burstin J, Aubert G, Huguet T, Ben C, Prosperi JM, Salon C, Munier-Jolain N (2012) Using a physiological framework for improving the detection of quantitative trait loci related to nitrogen nutrition in Medicago truncatula. Theor Appl Genet 124(4):755-768

Pierre JB, Huguet T, Barre P, Huyghe C, Julier B (2008) Detection of QTLs for flowering date in three mapping populations of the model legume species Medicago truncatula. Theor Appl Genet 117(4):609-620

Sankaran RP, Huguet T, Grusak MA (2009) Identification of QTL affecting seed mineral concentrations and content in the model legume Medicago truncatula. Theor Appl Genet 119(2):241-253

Stewart DW, Costa C, Dwyer LM, Smith DL, Hamilton RI, Ma BL (2003) Canopy structure, light interception, and photosynthesis in maize. Agron J 95(6):1465-1474
Tanksley SD (1993) Mapping polygenes. Annu Rev Genet 27(1): 205-233

Tong H, Mei H, Xing Y, Cao Y, Yu X, Zhang S, Luo L (2007) QTL analysis for morphological and physiological characteristics of flag leaf at the late developmental stage in rice. Chin J Rice Sci 19(2):493-499

Tornqvist CE, Taylor M, Jiang Y, Evans J, Buell CR, Kaeppler SM, Casler MD (2018) Quantitative trait locus mapping for flowering time in a lowland $\times$ upland switchgrass pseudo-F2 population. Plant Genome 11(2):241-253

Vandecasteele C, Teulat-Merah B, Morère-Le Paven MC, Leprince O, Ly VB, Viau L, Ledroit L, Pelletier S, Payet N, Satour P (2011) Quantitative trait loci analysis reveals a correlation between the ratio of sucrose/raffinose family oligosaccharides and seed vigour in Medicago truncatula. Plant Cell Environ 34(9):1473-1487

Voorrips R (2002) MapChart: software for the graphical presentation of linkage maps and QTLs. J Hered 93(1):77-78

Wassom JJ (2013) Quantitative trait loci for leaf angle, leaf width, leaf length, and plant height in a maize (Zea mays L) B73 $\times$ Mo17 population. Maydica 58(3):318-321

Wu QH, Chen YX, Zhou SH, Fu L, Chen JJ, Xiao Y, Zhang D, Ouyang SH, Zhao XJ, Cui Y (2015)High-density genetic linkage map construction and QTL mapping of grain shape and size in the wheat population Yanda1817 $\times$ Beinong6. PLoS One 10(2):e0118144

Zhang Y, Wang Y, Liu A, Xu SL, Zhao B, Zhang Y, Zou H, Wang W, Zhu H, Yan B (2016) Modulation of carbon nanotubes' perturbation to the metabolic activity of CYP3A4 in the liver. Adv Funct Mater 26(6):841-850

Zhang F, Kang J, Long R, Yu L-X, Wang Z, Zhao Z, Zhang T, Yang Q (2019)High-density linkage map construction and mapping QTL for yield and yield components in autotetraploid alfalfa using RAD-seq. BMC Plant Biol 19(1):165-171

Publisher's note Springer Nature remains neutral with regard to jurisdictional claims in published maps and institutional affiliations. 